\title{
Antagonists of the Mineralocorticoid Receptor or A New Pharmacological Class?
}

\section{Milla Marques Hermidorff ${ }^{1}$, Leonardo Vinícius Monteiro de Assis ${ }^{2}$ and Mauro César Isoldi ${ }^{1}$}

${ }^{1}$ Research Center in Biological Sciences, Department of Biological Science, Federal University of Ouro Preto (UFOP), Ouro Preto, Minas Gerais, Brazil ${ }^{2}$ Department of Physiology, Institute of Biosciences, University of São Paulo (USP), São Paulo, Brazil.

\section{Opinion}

A reduction in the blood pressure levels triggers, among other responses, a signaling cascade mainly controlled by the kidneys; this event is responsible for reestablishing the blood pressure, being known as renin, angiotensin, and aldosterone system - RAAS. The aldosterone, the last hormone released in this cascade, displays several effects in its target tissue such as kidneys, colon, brain, and cardiovascular system [1]; however, high levels of aldosterone, in certain diseases, lead to deleterious effects in most of these organs. In the next lines, our focus will be the on the cardiac tissue.

The deleterious effects of aldosterone over the cardiovascular system include left ventricle hypertrophy, congestive heart failure, vascular hypertrophy, and ventricular remodeling after myocardium infraction [2]. Most of the effects displayed by aldosterone are attributed to its binding to the mineralocorticoid receptor (MR); this receptor is localized in the cytoplasm in a perinuclear region. When aldosterone binds to MR a complex is formed, which then translocates to the nucleus where it binds to specific regions of the DNA that regulates the transcription of several genes [2]. The correlation between the deleterious effects of aldosterone through its binding to the MR has led to the development of MR antagonists. In this scenario spironolactone and then later on eplerenone started to be used in order to counteract the deleterious effects of aldosterone. More recently, firenone - a newer MR antagonist - has been developed with promising results $[3,4]$. Therefore, the MR antagonists have become the most used drugs to prevent decompensated heart failure and the progress of cardiac failure, and lethal arrhythmias [5].

However, later on it was observed that some of the effects attributed to the MR antagonists could not be linked solely to the antagonist profile of these drugs over the MR [6-8]. One of the first questions raised was: "Why do these antagonists display cardioprotective effects even in patients with low or normal levels of aldosterone?" Because of this, the possibility of a mechanism of action not restricted to the antagonism over the MR was discussed. Pre-clinical and clinical studies have shown that the MR antagonists promote substantial cardiovascular protection $[5,9]$ even in the absence of abnormal levels of aldosterone [6-8]. It was already known that spironolactone acted as an antagonist of other receptors; some of its side effects are linked to this profile since spironolactone binds to the androgen and progesterone receptor, which is associated with its sexual side effects [10]. Based on this, it was speculated that this nonspecific binding to the MR displayed by spironolactone could be related, at the least in some part, to its cardioprotective effects; however, this was disregarded with the development of eplerenone - an MR antagonist with low affinity but with a higher selectivity over the MR, which leads to reduced sexual side effects [11].

In the last decade, some groups have been studying the MR antagonists independently of its antagonism over aldosterone; these studies have shown that - independently of the serum levels of aldosterone - these drugs display an intrinsic action in its target tissues such as the heart. Then, this raised another question: "Could these effects be independent of the MR? Recently, our group has shown for the first time that both spironolactone and eplerenone display rapid cardioprotective effects, which are independently of their antagonism over aldosterone. These rapid effects include: increased levels of cGMP; $\mathrm{Ca}^{2+}$; cAMP; reduced fibroblast proliferation; and increased cardiomyocyte proliferation [12]. Due to the fast response displayed by the rapid pathway of aldosterone some groups have proposed that a membrane receptor is responsible for such events [13-15]. In fact, recently, it has been shown the participation of $G$ protein-coupled estrogen receptor (GPER) in mediating the rapid effects of aldosterone in the vascular system [16,17], and in the heart [18]. More remarkably both spironolactone and eplerenone have been shown to act as a partially GPER antagonist $[16,17,19]$. Since the MR antagonist may also act as GPER antagonist the priori used in several studies to differentiate between the genomic and rapid pathway triggered by aldosterone may be questioned [16,17].

Taken altogether, the MR antagonists show responses that are independent of aldosterone. Because these responses are fast in essence - seconds to minutes to take place - they are likely unrelated to a putative action of these drugs over the MR itself; in addition to the recent fact that GPER is a great candidate for mediating the rapid effects of aldosterone, this could be used to develop in the future antagonists of the rapid effects of aldosterone to be used, for instance, in the initial moments of acute myocardium infarction. Therefore, based on what was said before and with the fact that the MR antagonists display a wide range of biological effects, we then question ourselves the following: are they solely MR antagonist or are we looking at a new pharmacological class? And if so, what is its clinical relevance?

\section{Acknowledgement}

H.M.M is a fellow of CAPES; de Assis, L.V.M is a fellow of FAPESP (2013/24337-4). These authors contributed equally to this work. Our lab is funded by FAPEMIG (APQ-02112-10, APQ 00793-13) and CNPQ (CNPq 474174/2007-7)

\section{References}

1. Dooley R, Harvey BJ, Thomas W (2011) The regulation of cell growth and survival by aldosterone. Front Biosci (Landmark Ed) 16: 440-457.

2. Vizzardi E, Regazzoni V, Caretta G, Gavazzoni M, Sciatti E et al. (2014)

*Corresponding author: Mauro César Isoldi, Research Center in Biological Sciences Department of Biological Science, Federal University of Ouro Preto (UFOP), Ouro Preto, Minas Gerais, Brazil, E-mail: mauroisoldi@hotmail.com

Received: September 25, 2015; Accepted: September 28, 2015; Published: September 30, 2015

Citation: Hermidorff MM, de Assis LVM, Isoldi MC (2015) Antagonists of the Mineralocorticoid Receptor or A New Pharmacological Class? J Cell Sci Ther 6: 222. doi:10.4172/2157-7013.1000222

Copyright: (C) 2015 Hermidorff MM, et al. This is an open-access article distributed under the terms of the Creative Commons Attribution License, which permits unrestricted use, distribution, and reproduction in any medium, provided the original author and source are credited. 
Citation: Hermidorff MM, de Assis LVM, Isoldi MC (2015) Antagonists of the Mineralocorticoid Receptor or A New Pharmacological Class? J Cell Sci Ther 6: 222. doi:10.4172/2157-7013.1000222

Page 2 of 2

Mineralocorticoid receptor antagonist in heart failure: Past, present and future perspectives. IJC Heart \& Vessels 3: 6-14

3. Kolkhof P, Delbeck M, Kretschmer A, Steinke W, Hartmann E, et al. (2014) Finerenone, a novel selective nonsteroidal mineralocorticoid receptor antagonist protects from rat cardiorenal injury. Journal of cardiovascular pharmacology 64: 69-78

4. Pitt B, Kober L, Ponikowski P, Gheorghiade M, Filippatos G, et al. (2013) Safety and tolerability of the novel non-steroidal mineralocorticoid receptor antagonist BAY 94-8862 in patients with chronic heart failure and mild or moderate chronic kidney disease: a randomized, double-blind trial. European heart journal 34: 2453-2463.

5. Rossier MF, Python M, Maturana AD (2010) Contribution of mineralocorticoid and glucocorticoid receptors to the chronotropic and hypertrophic actions of aldosterone in neonatal rat ventricular myocytes. Endocrinology 151: 27772787.

6. Gaddam K, Corros C, Pimenta E, Ahmed M, Denney T, et al. (2010) Rapid reversal of left ventricular hypertrophy and intracardiac volume overload in patients with resistant hypertension and hyperaldosteronism: a prospective clinical study. Hypertension 55: 1137-1142.

7. Nishizaka MK, Zaman MA, Green SA, Renfroe KY, Calhoun DA (2004) Impaired endothelium-dependent flow-mediated vasodilation in hypertensive subjects with hyperaldosteronism. Circulation 109: 2857-2861.

8. Rocha R, Stier CT Jr, Kifor I, Ochoa-Maya MR, Rennke HG, et al. (2000) Aldosterone: a mediator of myocardial necrosis and renal arteriopathy. Endocrinology 141: 3871-3878.

9. Nagata K, Obata K, Xu J, Ichihara S, Noda A, et al. (2006) Mineralocorticoid receptor antagonism attenuates cardiac hypertrophy and failure in lowaldosterone hypertensive rats. Hypertension 47: 656-664.

10. Nappi JM, Sieg A (2011) Aldosterone and aldosterone receptor antagonists in patients with chronic heart failure. Vasc Health Risk Manag 7: 353-363.

11. Struthers A, Krum H, Williams GH (2008) A comparison of the aldosteroneblocking agents eplerenone and spironolactone. Clin Cardiol 31: 153-158.

12. Hermidorff MM, Faria Gde O, Amancio Gde C, de Assis LV, Isoldi MC (2015) Non-genomic effects of spironolactone and eplerenone in cardiomyocytes of neonatal Wistar rats: do they evoke cardioprotective pathways? Biochimie et biologie cellulaire 93: 83-93.

13. Chai W, Garrelds IM, de Vries R, Batenburg WW, van Kats JP, et al. (2005) Nongenomic effects of aldosterone in the human heart: interaction with angiotensin II. Hypertension 46: 701-706.

14. Falkenstein E, Christ M, Feuring M, Wehling M (2000) Specific nongenomic actions of aldosterone. Kidney Int 57: 1390-1394.

15. Dooley R, Harvey BJ, Thomas W (2012) Non-genomic actions of aldosterone: from receptors and signals to membrane targets. Mol Cell Endocrinol 350: 223-234.

16. Gros R, Ding Q, Sklar LA, Prossnitz EE, Arterburn JB, et al. (2011) GPR30 expression is required for the mineralocorticoid receptor-independent rapid vascular effects of aldosterone. Hypertension 57: 442-451.

17. Gros R, Ding Q, Liu B, Chorazyczewski J, Feldman RD (2-13) Aldosterone mediates its rapid effects in vascular endothelial cells through GPER activation. American journal of physiology Cell physiology 304: C532-C540.

18. Ashton AW, Le TY, Gomez-Sanchez CE, Morel-Kopp MC, McWhinney B et al. (2015) Role of Nongenomic Signaling Pathways Activated by Aldosterone During Cardiac Reperfusion Injury. Molecular endocrinology 29:1144-1155.

19. Ren Y, D'Ambrosio MA, Garvin JL, Leung P, Kutskill K, Wang H, et al. (2014) Aldosterone sensitizes connecting tubule glomerular feedback via the aldosterone receptor GPR30. American journal of physiology Renal physiology 307: F427-34
Citation: Hermidorff MM, de Assis LVM, Isoldi MC (2015) Antagonists of the Mineralocorticoid Receptor or A New Pharmacological Class? J Cell Sci Ther 6: 222. doi:10.4172/2157-7013.1000222
Submit your next manuscript and get advantages of OMICS Group submissions

\section{Unique features:}

- Increased global visibility of articles through worldwide distribution and indexing

- Showcasing recent research output in a timely and updated manner

- Special issues on the current trends of scientific research

Special features:

- 700 Open Access Journals

50,000 editorial team

Rapid review process

Quality and quick editorial, review and publication processing

Indexing at PubMed (partial), Scopus, DOAJ, EBSCO, Index Copernicus and Google Scholar etc Sharing Option: Social Networking Enabled

Authors, Reviewers and Editors rewarded with online Scientific Credits

Befter discount for your subsequent articles

Submit your manuscript at: http://www.editorialmanager.com/lifesciences 